\title{
Pd-Al Alloys Formation by Aluminium Underpotential Deposition on Palladium from Equimolar $\mathrm{AlCl}_{3}+\mathrm{NaCl} \mathrm{Melt}$
}

\author{
Nataša M. Vukićević ${ }^{1 *}$, Vesna S. Cvetkovićl ${ }^{1}$, Niko Jovićević ${ }^{2}$, Jovan N. Jovićević ${ }^{1}$ \\ ${ }^{1}$ University of Belgrade-Institute of Chemistry, Technology and Metallurgy, Department of \\ Electrochemistry, Njegoševa 12, 11000 Belgrade, Republic of Serbia \\ ${ }^{2}$ S\&R Company, Statesville, NC 28677, USA \\ "E-mail: vukicevic@ihtm.bg.ac.rs
}

doi: $10.20964 / 2021.06 .62$

Received: 7 March 2021 / Accepted: 21 April 2021 / Published: 30 April 2021

\begin{abstract}
The possibility of electrochemical underpotential deposition of aluminium onto palladium from equimolar $\mathrm{AlCl}_{3}+\mathrm{NaCl}$ melts at temperatures between $200{ }^{\circ}$ and $300{ }^{\circ} \mathrm{C}$ was investigated. Electrochemical techniques used were cyclic voltammetry, chronoamperometry, potentiodynamic polarization and open circuit measurements. The results were analyzed by SEM, EDX and XRD. It was found that aluminium deposits underpotentially onto palladium at around $0.200 \mathrm{~V}$ vs. Al from the chloroaluminate melt used. It was established that under the given conditions, Al underpotential deposition onto the palladium substrate can result in $\mathrm{AlPd}$ and $\mathrm{Al}_{3} \mathrm{Pd}_{4}$ alloy synthesis by solid-state interdiffusion. The surface alloys synthetized are well adhering, microcrystalline deposits, having highly developed surface area suitable for applications such as hydrogen purification filters.
\end{abstract}

Keywords: Aluminium alloys, electrodeposition, intermetallics, solid-state interdiffusion, X-ray diffraction $(\mathrm{XRD})$

\section{FULL TEXT}

(C) 2021 The Authors. Published by ESG (www.electrochemsci.org). This article is an open access article distributed under the terms and conditions of the Creative Commons Attribution license (http://creativecommons.org/licenses/by/4.0/). 